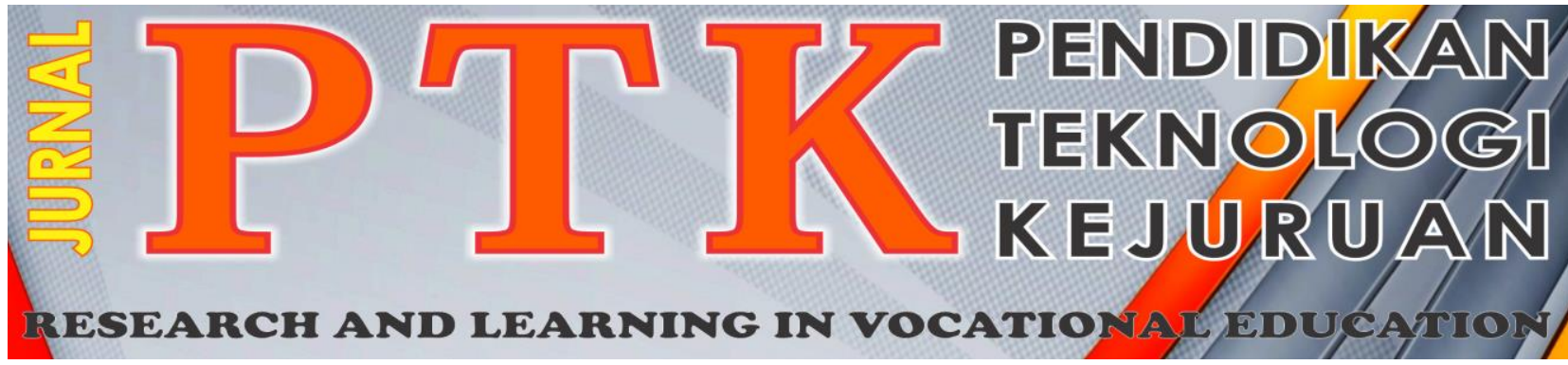

Vol. 2, No. 3, 2019

P-ISSN: 2621-3273

E-ISSN: 2621-1548

\title{
Pengembangan Media Pembelajaran Berbasis Web pada Mata Pelajaran Komputer dan Jaringan Dasar di SMK Negeri 1 Lembah Melintang
}

\author{
Harry Pratama Figna ${ }^{1}$, Kasman Rukun², Dedy Irfan ${ }^{3}$ \\ ${ }^{1}$ Jurusan Teknik Informatika, Fakultas Teknik, Universitas Negeri Padang \\ ${ }^{2}$ Pascasarjana Pendidikan Teknologi dan Kejuruan, Universitas Negeri Padang \\ E-mail:Harrypratamafigna@gmail.com, Kasman.rukun@gmail.com, irfankumango@gmail.com
}

\begin{abstract}
Abstrak-Penelitian ini bertujuan untuk mendapatkan media pembelajaran berbasis web yang valid, praktis, dan efektif pada mata pelajaran komputer dan jaringan dasar. Media pembelajaran berbasis web ini dirancang untuk dapat meningkatkan pemahaman siswa sehingga meningkatkan hasil belajar. Penelitian ini menggunakan metoda penelitian Research and Development ( $R$ and $D)$ dengan prosedur pengembangan 4-D (Define, Design, Develop, Desseminate). Teknik analisis data menggunakan teknik analisis deskriptif untuk mendeskripsikan validitas, praktikalitas, dan efetivitas media pembelajaran berbasis web. Hasil yang diperoleh dari penelitian pengembangan ini: (1) validitas media pembelajaran berbasis web dinyatakan valid pada aspek media dan aspek materi, (2) praktikalitas media pembelajaran berbasis web berdasarkan respon guru dan siswa dinyatakan sangat praktis, (3) efektivitas media pembelajaran berbasis web dinyatakan efektif dalam meningkatkan hasil belajar. Berdasarkan temuan penelitian ini disimpulkan bahwa media pembelajaran berbasis web dinyatakan valid, praktis, dan efektif untuk dimanfaatkan sebagai bahan ajar pada mata pelajaran komputer dan jaringan dasar.
\end{abstract}

Kata kunci: Media Pembelajaran, web, Pengembangan

Abstract-This research aims to get web-based learning media with a valid, practical, and effective on subjects the basic computer and network. This web-based learning media designed to improve the understanding of students thus increasing the learning results. This research uses research methods Research and Development $(R$ and $D)$ with 4-D development procedures (Define, Design, Develop, Disseminate). Data analysis techniques using descriptive analysis techniques for describing validity, practicalities, and web-based learning media efetivitas. The results obtained from the research of development: (1) the validity of a web-based learning media declared valid on aspects of media and materials, (2) a web-based learning media practicalities based on the response of teachers and students expressed very practical, (3) the effectiveness of web-based learning media declared effective in improving learning outcomes. Based on the findings of this study it was concluded that a web-based learning media declared valid, practical, and effective way to used as learning materials on subjects the basic computer and network.

Keywords：Learning Media, Web, Development

\section{Pendahuluan}

Pendidikan membentuk usaha sadar dan terencana untuk membangun keadaan belajar dan proses pembelajaran agar siswa bisa aktif dan membentuk kepribadian dalam dirinya. Pembentukan kepribadian dalam pendidikan terkait dengan upaya menanamkan nilai-nilai yang menjadi dasar kepribadian seseorang dan akan mewarnai kepribadian bangsa itu melakat kuat sebagai warna atau ciri khas suatu bangsa yang nampak dalam prilaku sehari-hari bangasa tersebut. Kemajuan bangsa tidak terlepas dari kemajuan yang dimulai dari sistem pendidikannya. Pendidikan pada dasarnya merupakan suatu proses komunikasi dan informasi dari pendidik ke siswa yang berisi informasi pendidikan berupa ilmu pengetahuan.

Pendidikan abad 21 menekankan penggunaan teknologi untuk meningkatkan proses pembelajaran, Standar guru abad 21 mengharuskan guru untuk menggunakan pengetahuan mereka tentang bahan ajar, proses pembelajaran, dan teknologi untuk menfasilitasi pengalaman belajar siswa (Smaldino, 
2014:19). Begitupun dengan siswa, standar teknologi pendidikan siswa abad 21 adalah proses pembelajaran memanfaatkan teknologi dan memungkinkannya pembelajaran secara mandiri (Smaldino, 2014:21). Berdasarkan standar pendidikan abad 21 penggunaan teknologi bukan suatu pilihan lagi, namun telah menjadi suatu keharusan demi meningkatkan proses pembelajaran.

Mengacu pada Undang-Undang Sistem Pendidikan Nasional menyebutkan bahwa, pendidikan kejuruan atau Sekolah Menengah Kejuruan (SMK) yang mempersiapkan peserta didik terutama untuk bekerja di bidang tertentu (UUSPN No. 20 Tahun 2003 pasal 15). Berdasarkan spektrum dan struktur kurikulum keahlian SMK bidang teknologi informasi dan komunikasi terdapat mata pelajaran Komputer dan Jaringan Dasar sebagai C2 Dasar Program Keahlian Untuk kelas X. Terdapat 9 kompetensi dasar yang harus dipelajari siswa pada semester 1 yakni menerapkan menerapkan K3LH disesuaikan dengan lingkungan kerja, menerapkan perakitan komputer, menerapkan pengujian perakitan komputer, menerapkan konfigurasi BIOS pada komputer menerapkan instalasi sistem operasi, menerapkan instalasi driver perangkat keras komputer, menerapkan instalasi software aplikasi menerapkan perawatan perangkat keras komputer, menganalisi permasalahan pada perangkat keras sembilan kompetensi tersebut harus dipahami siswa dengan baik. Agar kompetensi tersebut dapat tercapai diperlukan komponen-komponen pembelajaran yang dapat mendukung proses pembelajaran, namun selama proses pembelajaran masih menemui kendala.

Berdasarkan obeservasi awal yang dilakukan di SMKN 1 Lembah Melintang pada jurusan Teknik Komputer dan Jaringan (TKJ), masih terdapat beberapa masalah yang ditemukan. Pada mata pelajaran Komputer dan Jaringan Dasar belum terlaksana maksimal dan masih terdapat beberapa kendala dalam proses pembelajarannya, metode yang disajikan masih bersifat sederhana yakni guru menjelaskan materi dengan ceramah dan media yang dipakai masih bersifat modol cetak serta dibantu media proyektor serta media power point. Pada penggunaan modul cetak yang disajikan masih Media cetak biasa. Media power point yang disajikan oleh guru masih bersifat monoton mulai dari animasi yang belum kelihatan, serta audio dan video pada pembelajaran yang belum ada. Konten konten yang ada pada media sebelumnya masih sedikit. Dari penggunaan media yang ditawarkan oleh guru masih kurang terjadinya interaksi yang semestinya diharapkan.

Maka dari itu dibutuhkan media pembelajaran yang dapat menutupi kekurangan yang ada.
Sebagian dari siswa masih ada merasa kesulitan memahami materi pembelajaran, dari hasil wawancara yang dilakukan pada guru kelas $\mathrm{X}$ jurusan TKJ siswa merasa kerumitan menafsirkan materi pembelajaran contohnya saja pada Kompetensi Dasar 3.2 mengenai menerapkan perakitan komputer. Pada pelajaran ini siswa membutuhkan pemahaman khusus mulai dari proses menentukan spesifikasi komputer sesuai kebutuhan pekerjaan, melakukan perakitan komputer sesuai standar industri, menjelaskan bagian- bagian perangkat keras komputer. Karena materi pembelajaran tersebut membutuhkan pemahaman yang khusus dari abstrak ke konkrit. Kemudian pada kegiatan pembelajaran, beberapa siswa memperhatikan dan menyalin apa yang dikatakan guru ke bukunya hal ini tidak efisien dari segi waktu. Pelaksanaan proses pembelajaran yang dilakukan Permasalahan tersebut mengindikasikan bahwa materi pelajaran belum tersampaikan secara tuntas. Kemudian bagi siswa, dibutuhkan waktu yang lebih banyak untuk memahami materi secara berulang-ulang diluar sekolah. Aktivitas ini berdampak siswa menjadi kurang aktif dalam kegiatan belajar mengajar.

Kondisi seperti ini berdampak pada hasil belajar mata pelajaran Komputer dan Jaringan Dasar kelas $X$ TKJ SMKN 1 Lembah Melintang yang tengah tergolong rendah, rendahnya nilai belajar siswa merupakan pengaruh dari beberapa masalah yang telah dijelaskan. Persentase ketuntasan ujian tengah semester genap kelas $\mathrm{X}$ TKJ tahun pelajaran 2017/2018 masih belum mencapai sarat ketuntasan yang diminta oleh sekolah dan hal tersebut dapat dibuktikan sebagai berikut :

Tabel 1. hasil belajar komputer dan jaringan dasar semester ganjil kelas X TKJ SMKN 1 Lembah melintang.

\begin{tabular}{ccccc}
\hline \multirow{2}{*}{ Jumlah } & \multicolumn{4}{c}{ Ketuntasan } \\
Siswa & Nilai $\geq 75$ & \multicolumn{2}{c}{ Nialai $<75$} \\
& Jumlah & $\%$ & Jumlah & $\%$ \\
\hline 34 & 13 & $38.2 \%$ & 21 & $61.7 \%$
\end{tabular}

Berdasarkan Tabel 1.1, dapat diketahui masih ada beberapa siswa yang tidak mencapai KKM yaitu sebanyak $61.7 \%$ atau 21 dari 34. Dari Tabel 1.1 tersebut dijelaskan bahwa nilai belajar siswa pada mata pelajaran Komputer dan Jaringan Dasar masih dapat ditingkatkan. Faktor yang diprediksi yang mempengaruhi hasil belajar siswa adalah kurangnya konsentrasi siswa terhadap materi yang disampaikan oleh gruru serta kurangnya jam pelajaran sewaktu kegiatan belajar mengajar. Adapun fasilitas penunjang pembelajaran yang ada di SMKN 1 Lembah Melintang cukup bagus dan baik untuk digunakan, seperti pada labor komputer terdapat 40 unit komputer yang aktif masing-masing spesifikasi 
core i3 dan sudah terkoneksi internet, fasilitas hot spot sudah terpasang 4 titik yaitu di labor TKJ, ruang majelis guru, ruang tata usaha dan di perpustakaan.

Melihat beberapa masalah yang terjadi pada mata pelajaran Komputer dan Jaringan Dasar tersebut, pemanfaatan media pembelajaran berbasis web perlu ada dalam pembelajaran. Dengan menggunakan media web siswa dapat menguasai materi pembelajaran dengan cepat dan menjadi lebih aktif. Sedangkan bagi guru media ini dapat membatu, jika biasanya guru harus membuat media pembelajaran dengan cara manual dan kemungkinan besar media pembelajaran yang dibuat tidak akan bertahan lama. Maka lain halnya jika dengan menggunakan media elektronik, selain media pembelajaran akan lebih tahan dan awet karena disimpan dalam bentuk file dan penggunaan media web ini lebih mudah dan praktis digunakan dimana saja dan kapan saja. Media ini memanfaatkan teknologi yang terhubung dengan jaringan internet yang prinsip kerjanya adalah pembelajaran dapat dilaksanakan menggunakan konsep E-learning (pembelajaran secara elektronik). untuk penggunaan media web ini lebih mudah dan praktis. Hanya perlu menyalakan laptop, komputer serta smartphone yang terkoneksi internet siswa langsung bisa diperlihatkan materimateri pelajaran yang akan dipelajari.

Berdasarkan fenomena-fenomena diatas untuk itu penulis merasa perlu berkontribusi agar pembelajaran Komputer dan Jaringan Dasar dapat meningkat, salah satu pemecahan masalahnya adalah dengan Pengembangan Media Pembelajaran berbasis Web Pada Mata Pelajaran Komputer dan Jaringan Dasar di SMKN 1 Lembah Melintang.

\section{METODE}

Jenis penelitian yang digunakan adalah penelitian pengembangan (research and development). Penelitian pengembangan adalah penelitian yang digunakan untuk menghasilkan produk tertentu dan menguji keefektifan produk tersebut (Sugiyono, 2012:297).

Prosedur pengembangan media pembelajaran berbasis web pada mata pelajaran komputer dan jaringan dasar ini menggunakan model pengembangan 4-D (four-D). Proses pengembangan yang terdiri dari 4 tahap yaitu: (1) Pendefinisian (Define); (2) Perancangan (Design); (3) Pengembangan (Develop); (4) Penyebaran (Disseminate) (Thiagarajan, 1974).

Tahap yang pertama adalah tahap pendefinisian yakni berkenaan dengan analisis kebutuhan, siswa, analisis tugas, analisis konsep dan perumusan tujuan pembelajaran. Tahap yang kedua adalah tahap perancangan yakni penyusunan standar tes, pemilihan media, pemilihan format, dan membuat rancangan awal.

Tahap yang ketiga adalah tahap pengembangan yakni validasi media pembelajaran oleh ahli, uji praktikalitas dengan observasi langsung, oleh siswa dan guru, uji efektifitas dengan tes hasil belajar. Tahap yang keempat adalah tahap penyebaran yakni mempromosikan produk pengembangan agar bisa diterima oleh pengguna, baik individu, suatu kelompok.

\section{HASIL DAN PEMBAHASAN}

Hasil penelitian yang telah dilakukan adalah sebuah media pembelajaran berbasis web yang valid, praktis dan efektif pada mata pelajaran komputer dan jaringan dasar kelas X SMKN 1 Lembah Melintang. Hasil perancangan media pembelajaran berbasis web dapat dilihat pada gambar 1, gambar 2 dan gambar 3.

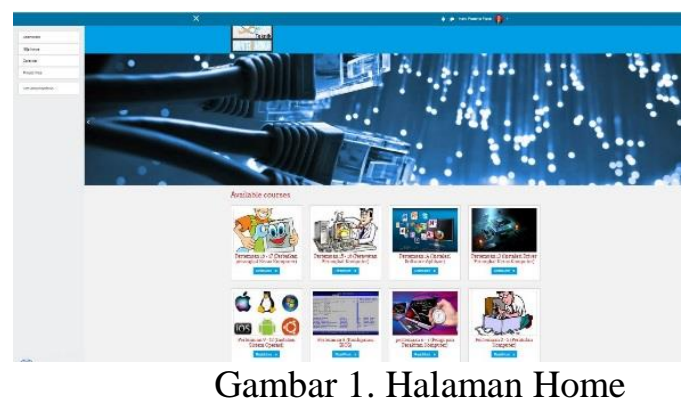

Halaman home ini terdapat beberapa pilihan materi pembelajaran, mulai dari materi pertemuan 1 sampai dengan pertemuan 16 .

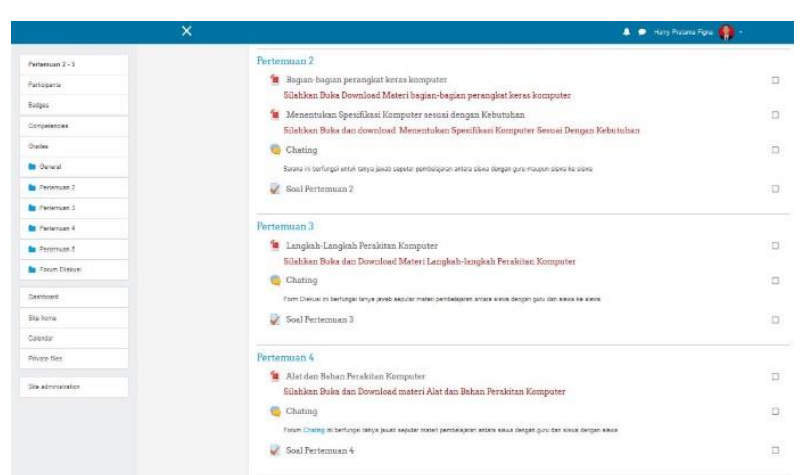

Gambar 2. Halaman Materi

Halaman menu materi merupakan halaman yang berisikan tentang materi pembelajaran, latihan soal, sara diskusi sera video penunjang pembelajaran. 


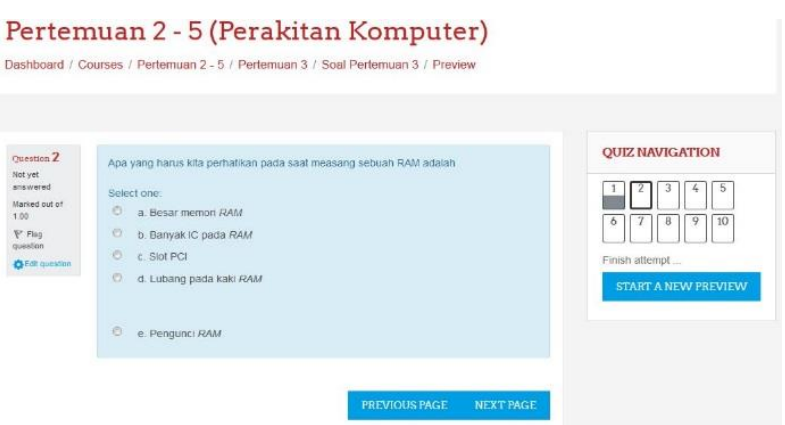

Gambar 3. Halaman latihan soal

Halaman latihan yang berisi latihan latihan soal setiap pertumuan, latihan soal ini terdiri dari 10 soal dan jawaban dengan pilihan ganda.
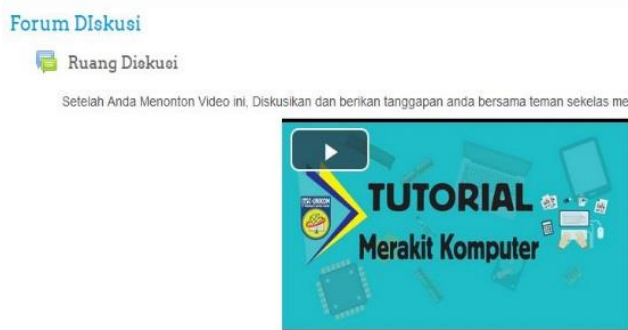

Gambar 4. Halaman form diskusi

Halaman diskusi merupakan merupakan sarana komunikasi yang bebas yang dikhususkan untuk siswa untuk saling berinteraksi dalam memperkaya ilmu pengetahuan yang dimilikinya

Media yang telah selesai dirancang diuji validitasnya. Validasi dilakukan oleh 3 orang pakar ahli media dan 3 orang pakar ahli materi. Aspek media yang divalidasi adalah aspek didaktik, kontruksi dan teknis. Aspek materi yang divalidasi adalah kualitas materi, dan kualitas pembelajaran. Hasil yang didapat merupakan nilai validasi terhadap rancangan media pembelajaran, yang dirangkum sebagaimana terlihat pada tabel 2.

Tabel 2. Hasil Validasi Media Pembelajaran Berbasis web.

\begin{tabular}{clcc} 
No & Validator & $\begin{array}{c}\text { Koefisien } \\
\text { Aiken's V }\end{array}$ & Klasifikasi \\
\hline 1 & Ahli Media & 0,87 & Valid \\
2 & Ahli Materi & 0,83 & Valid
\end{tabular}

Hasil analisis uji validitas kepada ahli media diperoleh rata-rata aspek sebesar 0,87>0,66, hasil validasi dengan ahli materi diperoleh ratarata sebesar 0,83>0,66. Jadi, media pembelajaran berbasis web dinyatakan valid dari ahli media dan ahli materi.

Media telah dinyatakan valid selanjutnya dilakukan uji praktikalitas. Media pembelajaran berbasis web dikatakan memiliki praktikalitas yang tinggi apabila bersifat praktis, dan mudah penggunaannya. Data uji praktikalitas diperoleh dari pengisian angket kepraktisan media web. Responden yang menilai kepraktisan media pembelajaran berbasis web ini adalah guru mata pelajaran Komputer dan Jaringan Dasar dan siswa. Uji praktikalitas ini dilakukan terhadap pengguna, yaitu siswa dan guru. Hasil penilaian praktikalitas siswa dan guru terhadap media pembelajaran berbasis web terdapat dalam tabel 3.

Tabel 3. Hasil Respon Siswa dan Guru

\begin{tabular}{llc}
\hline No & Responden & Tingkat Pencapaian (\%) \\
\hline 1 & Siswa & 86,19 \\
2 & Guru & 86,00 \\
Rata-Rata & 86,09
\end{tabular}

Kategori Aspek Sangat Praktis

Hasil analisis praktikalitas media pembelajaran berdasarkan respon siswa dan guru sebesar 86,09 dengan kategori sangat praktis Jadi dapat disimpulkan bahwa media pembelajaran berbasis web dinyatakan sangat praktis.

Media pembelajaran berbasis web yang sudah dinyatakan praktis, selanjutnya diujicobakan pada 35 siswa kelas X SMKN 1 Lembah Melintang. Efektivitas media pembelajaran berbasis web dilihat dari tes hasil belajar.

Hasil analisis efektivitas media pembelajaran dilihat dari ketuntasan klasikal didapatkan 91,43\% siswa dinyatakan tuntas, dimana sebanyak 32 siswa mendapatkan nilai diatas Kriteria Ketuntasan Minimum (KKM) yakni 75. Hasil efektivitas juga dilihat dari perbandingan pre-test dan post-test menggunakan gain score yang dapat dilihat pada tabel 4

Tabel 4. Nilai Gain Score

\begin{tabular}{|c|c|c|c|}
\hline $\mathrm{N}$ & $\begin{array}{c}\text { Nilai } \\
\text { Minimum }\end{array}$ & $\begin{array}{c}\text { Nilai } \\
\text { Maksimum }\end{array}$ & $\begin{array}{l}\text { Gein } \\
\text { Score }\end{array}$ \\
\hline 30 & 0.23 & 0.90 & 0,57 \\
\hline
\end{tabular}

Hasil analisis data pre-test dan post-test dengan gain score diperoleh nilai gain score 0,57 $\geq 0,3$ dengan kategori sedang. Berdasarkan ketuntasan klikal dan nilai gain score dapat disimpulkan bahwa media pembelajaran berbasis web yang dikembangkan efektif untuk meningkatkan pemahaman materi bagi siswa.

Berdasarkan hasil analisis data penelitian yang telah dilakukan, diperoleh hasil validasi media dan materi telah baik dan dapat di uji cobakan dilapangan. Nana dan Ahmad (2013) bahwa media pembelajaran hendaknya memenuhi syarat mudah dilihat (visible), menarik (interesting), dan tepat (accurate), yakni media harusnya dapat dibaca dengan mudah, didesain dengan menarik sehingga dapat memotivasi siswa, dan media sesuai dengan karakteristik materi pembelajaran. Hasil penilaian ini juga relevan dengan hasilhasil penelitian yang terdahulu yang dilakukan oleh Doni (2015) yang menunjukkan validasi 
pada aspek media dan aspek materi dinyatakan valid dan telah dapat di uji cobakan dilapangan.

Hasil uji praktikalitas media pembelajaran berdasarkan respon guru dan siswa dinyatakan sangat praktis, sehingga disimpulkan bahwa media pembelajaran berbasis web praktis dalam penggunaan. Sesuai dengan pendapat Nana dan Ahmad (2013) bahwa media pembelajaran harus memiliki nilai kepraktisan dan kesederahanaan sehingga dapat digunakan dengan mudah. Hasil penilaian ini juga relevan dengan hasil-hasil penelitian yang terdahulu yang dilakukan oleh Tri (2016) yang menyatakan bahwa media yang dikembangkan praktis untuk digunakan oleh guru dan siswa.

Hasil efektivitas ditinjau dari perbandingan hasil belajar antara pre-test dan post-test, didapatkan perbandingan setelah menggunakan media pembelajaran berbasis web. Oleh sebab itu, media pembelajaran berbasis web efektif dilihat dari hasil belajar siswa. Sejalan dengan pendapat Wina (2012) bahwa media pembelajaran yang digunakan harus memperhatikan efektifitas dalam penggunaannya sehingga dapat memudahkan pencapaian tujuan pembelajaran.

\section{KESIMPULAN}

Penelitian ini telah menghasilkan bahan ajar komputer dan jaringan dasar dengan media pembelajaran berbasis web pada kelas X Bidang keahlian Teknik Komputer dan Jaringan.

Bahan ajar komputer dan jaringan dasar dengan media pembelajaran berbasis web yang dikembangkan telah dinyatakan valid setelah divalidasi oleh 6 orang validator, 3 orang untuk validasi media dan 3 orang untuk validasi materi. Hasil penilaian untuk validasi media validasi materi dinyatakan valid oleh validator.

Bahan ajar komputer dan jaringan dasar dengan media pembelajaran berbasis web yang dikembangkan dapat dikatakan praktis setelah dilakukan uji coba pada guru mata pelajaran Komputer dan Jaringan Dasar dan siswa. Hasil penilaian guru dan siswa terhadap praktikalitas media pembelajara berbasis web ini menyatakan bahwa media pembelajaran berbasis web berada pada kategori sangat praktis.

Bahan ajar komputer dan jaringan dasar dengan media pembelajaran berbasis web ini telah melalui tahapan uji efektifitas melalui tes hasil belajar siswa, yaitu berupa pretest dan postest. Hasil uji keefektifan menyatakan bahwa media pembelajaran berbasis web ini dalam kategori efektif. Dibuktikan dengan hasil belajar siswa yang mengalami peningkatan.

\section{DAFTAR PUSTAKA}

[1] Daryanto. Pengembangan Perangkat Pembelajaran (Silabus, RPP, PHB, Bahan Ajar). Yogyakarta: Gava Media. 2013.

[2] Doni kurniawan. Pengembangan Multimedia Interkatif pada Mata Pelajaran Mendiagnosis Permasalahan dan Pengoperasian Komputer di Kelas X SMK Negeri 1 Hiliran Gumanti. Tesis. Padang: Universistas Negeri Padang. 2015.

[3] Depdikbud. PP Nomor 32 Tahun 2013 Tentang Standar Nasional Pendidikan. Jakrta: Depdiknas. 2013.

[4] Nana Sudjana, Ahmad Rifai. Media Pengajaran. Bandung:Sinar Baru Algesindo. 2013.

[5] Sugiyono. Metode Penelitian Pendekatan Kualitatif, Kuantitatif dan $R \& D$. Bandung : Alfabeta. 2012.

[6] Thiagarajan, at al. Instructional Development for Training Teachers of Exceptional Children. Bloomington: Indiana University. 1974.

[7] Yogi Irdes Putra. Pengembangan Media Web Based Learning Pada Mata Pelajaran Perakitan Komputer Kelas X Smk adzkia Padang. Tesis. Padang: Universitas Negri Padang. 2017.

[8] Smaldino. at al. Intructional technologiy and media of learning. New Jersey: Meril Prentice Hall. 2014.

\section{Biodata Penulis}

Harry Pratama Figna, dilahirkan di Air Bangis, 27 September 1993. Menyelesaikan S1 pada jurusan Pendidikan Teknik Informatika dan Komputer UPIYPTK Padang tahun 2015 dan pendidikan Pascasarjana (S2) Magister Pendidikan Teknik bidang Pendidikan Teknik Informatika dan Komputer pada tahun 2016.. 